\title{
Film animowany w perspektywie filozofii mediów Gianniego Vattima
}

\author{
Michał Wieczorek \\ (Dublin City University)
}

\section{Wprowadzenie}

Niniejszy artykuł ma na celu przedstawienie interesujących cech filmu animowanego z perspektywy filozofii mediów Gianniego Vattima. Przybliżę w nim, na czym w ocenie tego myśliciela polega emancypujący i wzbogacający ludzkie doświadczenie świata charakter mediów masowych powiązany z wrażeniem oscylacji, które zaprezentuję za Vattimem na podstawie filmu. Następnie, przybliżając rozważania włoskiego filozofa na temat kategorii odrzeczywistnienia i jego granic (które uniemożliwiają zajście efektu oscylacji), pokażę, dlaczego w moim przekonaniu to film animowany można uznać za medium w sposób szczególny pasujące do filozofii Vattima i związanych z nią etyczno-politycznych nadziei. Przedstawię, dlaczego wyraźne oderwanie obrazów świata prezentowanych w filmie animowanym od rzeczywistości czyni $z$ animacji formę sztuki najlepiej realizującą opisywany przez Vattima charakter mediów masowych.

Choć Vattimo znany jest przede wszystkim ze swojej radykalnej filozofii hermeneutycznej podejmującej zagadnienia nihilizmu i interpretacyjnego charakteru wiedzy oraz formułującej koncepcję prawdy, która nie sprowadza tejże do zgodności sądu z rzeczywistością ${ }^{1}$, $\mathrm{w}$ książce Społeczeństwo

\footnotetext{
Więcej na ten temat zob. A. Zawadzki, Koniec nowoczesności: nihilizm, hermeneutyka, sztuka, w: G. Vattimo: Koniec nowoczesności, tłum. M. Surma-Gawłowska, Universitas, Kraków 2006, s. V-XXI oraz F. D'Agostini, Vattimo's Theory of Truth, w: Between Nihilism and Politics: The Hermeneutics of Gianni Vattimo, eds. S. Benso, B. Schroeder, State University of New York Press, Albany, New York 2010 s. 33-46.
} 
przejrzyste ${ }^{2}$ przedstawił on niezwykle interesującą i oryginalną analizę mediów masowych. Całościowe przyjrzenie się jego namysłowi nad techniką ${ }^{3}$ pozwala mówić o Vattima filozofii techniki i mediów.

Jednym z jej centralnych elementów jest przekonanie włoskiego filozofa, że wraz z rozwojem technologii komunikacyjnych dochodzić będzie do reprodukcji coraz większej liczby obrazów świata. Ma to dla autora Końca nowoczesności pozytywny wymiar ${ }^{4}$, gdyż konkurujące ze sobą kanały rozpowszechniania informacji powinny w jego przekonaniu przedstawiać wydarzenia $z$ coraz to nowych perspektyw, zwiększając zasięg i znaczenie interpretacji rzeczywistości, które dotychczas nie znajdywały dostatecznego wydźwięku.

Różnice między poszczególnymi interpretacjami, wynikające m.in. z wielości punktów widzenia i nastawienia interpretujących, prowadzić miałyby do nieustającego konfliktu interpretacji, w wyniku którego osłabione zostaną w istocie metafizyczne koncepcje postulujące istnienie jedynego zasadnego opisu rzeczywistości. Zdaniem Vattima w dobie mediów masowych świat rozumiany będzie w sposób lżejszy, bardziej swobodny i emancypujący rozmaite grupy, które dotychczas nie dysponowały środkami umożliwiającymi dołączenie do głównego nurtu obiegu informacji. Ostatecznie, rzeczywistość epoki mediów masowych jest w jego przekonaniu niczym więcej jak „rezultatem krzyżowania się [...] wielości obrazów, interpretacji, rekonstrukcji, które niekoordynowane przez jakiekolwiek «centrum», rozpowszechniają konkurujące ze sobą media"5.

\section{Oscylacja}

Kluczowym dla opisu sytuacji, w której znajdować miałby się współczesny podmiot, jest dla Vattima pojęcie oscylacji ${ }^{6}$, silnie związane $\mathrm{z}$ jego koncepcjami

Zob. G. Vattimo, Społeczeństwo przejrzyste, tłum. M. Kamińska, Wydawnictwo Naukowe Dolnośląskiej Szkoły Wyższej Edukacji TWP, Wrocław 2006.

3 Na pewne jego elementy wskazują Ashley Woodward (zob. A. Woodward, Being and Information: On the Meaning of Vattimo, „Philosophy Today” 2016, No. 3(60), s. 723-41) oraz Erik M. Vogt (zob. E.M. Vogt, Postmodernity as the Ontological Sense of Technology and Democratic Politics, w: Between Nihilism and Politics: The Hermeneutics of Gianni Vattimo, eds. S. Benso, B. Schroeder, State University of New York Press, Albany, New York, 2010 s. 221-240).

4 Zob. G. Vattimo, Społeczeństwo przejrzyste, dz. cyt., s. 15-24.

5 Tamże, s. 21.

6 Zob. tamże, s. 55-70. 
estetycznymi ${ }^{7}$. Włoski filozof twierdzi, że odbiorca przekazów dobywających się z mediów masowych będzie bezustannie wystawiany na odmienne rozumienia rzeczywistości, co doprowadzi do pewnego rozchwiania. Kontakt z często sprzecznymi interpretacjami bieżących wydarzeń i obowiązujących światopoglądów powinien doprowadzić do sytuacji, w której żadne przekonanie nie może być traktowane jako pewne i oczywiste. Współczesny podmiot oscyluje zatem pomiędzy wieloma możliwymi i zasadnymi odczytaniami swojego otoczenia, dokonując prób zorientowania się w obliczu niezwykle szybko przekształcających się treści doświadczenia. Choć Vattimo rozumie przez oscylację odczucie znajdujące się pomiędzy opisywanym przez Martina Heideggera zjawiskiem Sto $\beta^{8}$ i uczuciem shocku przedstawionym przez Waltera Benjamina ${ }^{9}$, dla potrzeb moich rozważań istotniejsze jest odwołanie do tego drugiego. W swojej interpretacji Benjamina Vattimo podkreśla przede wszystkim zawrotne tempo oraz ogromną intensywność bodźców docierających zewsząd do współczesnego człowieka.

Ukazując shock jako doświadczenie podwyższonej uwagi w obliczu zmieniającego się bez przerwy otoczenia, włoski filozof zwraca uwagę między innymi na możliwe porównanie do sytuacji przechodnia, który zmuszony jest do reagowania na zagrożenie związane z ruchem przemykających wokół niego samochodów. Vattimo dostrzega też, co istotne, zasadność przywołania filmu jako formy sztuki, w której shock odznacza się w sposób najpełniejszy. Podobnie jak prowokacyjne dzieła sztuki dadaistycznej film składa się z pocisków wymierzonych „w kierunku widza, w jego bezpieczeństwo, w oczekiwania jego zmysłów czy przyzwyczajenia percepcyjne"10 i dostrzegalne jest to przede wszystkim w warstwie montażowej. Jak pisze Vattimo, „powstały obraz jest natychmiast zastępowany obrazem następnym, a oczy i umysł widza muszą się do niego przystosować”"1. Cięcia filmowe, tworzące interpretowalne sekwencje następujących po sobie obrazów, są dla widza czymś nowym, zmuszającym go do zorientowania się w nieznanej sytuacji i sensownego wypełnienia luki powstałej między dwoma ujęciami. Musi on za

Te dobrze przybliżyła Anna Ziółkowska-Juś (zob. A. Ziółkowska-Juś, Doświadczenie estetyczne w świecie późnej nowoczesności. W horyzoncie hermeneutyki Gianniego Vattimo, „Estetyka i Krytyka" 2017, nr 2(45), s. 155-174).

8 Zob. M. Heidegger, Źródło dzieła sztuki, w: tegoż, Drogi lasu, tłum. J. Mizera, Aletheia, Warszawa 1997, s. 7-62.

9 Zob. W. Benjamin, Dzieło sztuki w dobie reprodukcji technicznej, w: tegoż, Anioł historii. Eseje, szkice, fragmenty, tłum. J. Sikorski, Wydawnictwo Poznańskie, Poznań 1996, s. 201-240.

10 G. Vattimo, Społeczeństwo przejrzyste, dz. cyt., s. 59.

11 Tamże. 
pomocą wyobraźni aktywnie dopasować swoje rozumienie odbieranych treści do tego, jak mógł „widzieć” je twórca (bez tego byłyby jedynie niezrozumiałym ciągiem obrazów), i wydaje mi się, że konieczne jest to nie tylko do uporządkowania poszczególnych ujęć w spójną całość, ale wpływa na możliwość postrzegania w sposób filmowy ${ }^{12}$ - a więc postrzegania postaci, rekwizytów, scenografii czy dźwięków raczej przez pryzmat ich znaczenia w kontekście danego filmu, a nie ich dosłownego znaczenia, jakie mogłyby mieć poza ekranem. Mam tu na myśli chociażby to, że potwór niszczący makietę miasta dzięki takiej filmowej percepcji niszczy samo miasto (przynajmniej na poziomie świata przedstawionego), podczas gdy znani aktorzy postrzegani są przez widzów jako postaci odgrywane w filmie, a nie jako ludzie, na których przy odrobinie szczęścia można natknąć się na ulicy.

Rozumiana w ten sposób oscylacja - umożliwiająca nowe rozumienie dotychczas postrzeganych zjawisk i dostrzeżenie zjawisk radykalnie nowych (oraz wymuszająca dopasowanie tego rozumienia i tych zjawisk do istniejącego światopoglądu) - powinna być w przekonaniu Vattima stanem, w który publiczność mediów masowych wpadać będzie właściwie bezustannie. Podmiot wystawiony na wpływ nieskończonej liczby konkurujących ze sobą przekazów medialnych miałby raz po raz oscylować i na nowo orientować się w swoim odniesieniu do świata, za każdym razem rozszerzając swoje wyobrażenie o zasadnych interpretacjach rzeczywistości. W rezultacie społeczeństwo mediów masowych powinno charakteryzować się według Vattima większą otwartością na różnego rodzaju mniejszości i odmienne sposoby myślenia. Jak nietrudno zauważyć i jak zaznacza włoski filozof w swojej rewizji wcześniejszych poglądów na temat mediów ${ }^{13}$, tak się jednak nie stało. Z perspektywy Vattima można powiedzieć, że społeczeństwo nie zbliżyło się do spełnienia optymistycznych nadziei włoskiego filo-

12 Należy przypomnieć, że choć skupiam się tu jedynie na Benjaminowskim wymiarze oscylacji (który Vattimo przedstawia ze względu na jego powszechność), zjawisko to ma także wiele wspólnego z Heideggerowskim Sto $\beta$, zachodzącym wtedy, gdy dzieło sztuki w fundamentalny sposób zmienia ludzkie rozumienie - oscylacja w rozumieniu Vattima zachodzi równie często co shock, jednak odznacza się siłą oddziaływania zbliżoną do zjawiska opisywanego przez Heideggera. W tym sensie, sposoby postrzegania obiektów umożliwione (i w pewnym sensie wymuszone) przez film, można rozumieć jako radykalnie nowe formy interpretowania zjawisk. Mam na myśli esej Granice odrzeczywistnienia, który ukazał się w roku 2000 i stał się częścią drugiego wydania Społeczeństwa przejrzystego jako uzupełnienie wcześniejszych twierdzeń filozofa i na podstawie którego opisuję kategorię odrzeczywistnienia. Zob. G. Vattimo, Społeczeństwo przejrzyste, dz. cyt., s. 126-40. 
zofa. Z perspektywy dzisiejszej należałoby wręcz zauważyć, że rozwój mediów masowych doprowadził do postępującej polaryzacji poszczególnych grup i ich zamykania się wewnątrz odrębnych „baniek medialnych”14.

\section{Odrzeczywistnienie}

Według autora Końca nowoczesności problem ten wiąże się z czymś, co określa on jako granice odrzeczywistnienia. By do oscylacji zachodziło, publiczność mediów masowych musi odbierać nie tylko więcej przekazów, lecz także więcej różnych przekazów reprezentujących możliwie najwięcej odmiennych od siebie perspektyw. Dla Vattima niezbędna do oscylacji pełna kreatywność w formułowaniu interpretacji możliwa jest jedynie wtedy, gdy spektrum zasadnych rozumień nie jest w sztuczny sposób ograniczone przez rozmaite zasady rzeczywistości określające z góry, co może być rozumiane jako prawdziwe i akceptowalne. Do takich zasad można zaliczyć chociażby klasyczne konstrukcje metafizyczne, ściśle determinujące, czym jest i czym może być prawda, oraz wykluczające wszelkie odmienne rozumienia, często za pomocą przemocy (zarówno fizycznej i symbolicznej) ${ }^{15}$. Jednak według Vattima najważniejsza $\mathrm{z}$ takich zasad wiąże się ściśle $\mathrm{z}$ mechanizmami rynkowymi. Już Karol Marks pokazywał, w jaki sposób zachodzące w społeczeństwie stosunki ekonomiczne naturalizowane są przez przedstawicieli klas panujących, a prawa ekonomii prezentowane jako konieczne ${ }^{16}$. Vattimo argumentuje w podobny sposób, wskazując, że spektrum perspektyw i interpretacji reprodukowanych $\mathrm{w}$ dzisiejszych mediach jest ściśle powiązane $\mathrm{z}$ logiką zysku. Do głosu dochodzą tylko te stanowiska i reprezentowane są jedynie te wizje świata, które właściciele koncernów medialnych uznali za dostatecznie bezpieczne i przystępne dla przeciętnego odbiorcy. Reprodukcja obrazów świata ma przynosić zysk, nie prowadząc zarazem do nadmiernego ryzyka utraty pieniędzy. W związku z tym media reprodukują według Vattima obrazy znane, nie-

14 Więcej na ten temat zob. C.R. Sunstein, \#Republic: Divided Democracy in the Age of Social Media, Princeton University Press, Princeton 2017.

15 Jak zauważa Santiago Zabala, jednym z celów filozofii Vattima jest redukcja wszelkich form przemocy poprzez osłabienie jej metafizycznych podstaw. Zob. S. Zabala, Introduction: Gianni Vattimo and Weak Philosophy w: tegoż, Weakening Philosophy: Essays in Honour of Gianni Vattimo, McGill-Queen's University Press, Montreal, Kingston 2007, s. 30.

16 Zob. K. Marks, Proces wytwarzania kapitału, red. P. Hoffman, B. Minc i E. Lipiński Książka i Wiedza, Warszawa 1951, s. 76-89. 
prowokujące do myślenia i oscylacji oraz banalne - pełen kiczu język wizualny, jakim posługuje się reklama, jest w moim przekonaniu doskonałym przykładem podporządkowania treści i formy przekazu zobiektywizowanym prawom ekonomii. Choć warto zastanowić się, czy argumentacja Vattima pozostaje aktualna w świecie dziennikarstwa obywatelskiego, alt-mediów - czy nawet mediów społecznościowych, w których każdy użytkownik Internetu może rozpowszechniać interpretacje świata nieobecne w mediach głównego nurtu - na potrzeby tego eseju zagadnienie granic odrzeczywistnienia traktuję w jego wąskim, przedstawionym przez Vattima, sensie. Odrzeczywistnienie jest zatem tym, co pozwala na tworzenie treści istotnie umożliwiających ich odbiorcom oscylację. Oderwanie się od rozmaicie rozumianych zasad rzeczywistości polega na zdystansowaniu się od tego, co wyznacza, o czym, w jaki sposób i z jakiej perspektywy można mówić, podczas gdy granice odrzeczywistnienia zmuszają do przedstawiania zjawisk w taki sposób, by powstałe opisy zmieściły się w spektrum akceptowalnych interpretacji. Mówiąc krótko, by media masowe osiągnęły potencjał, jaki zauważył w nich Vattimo, niezbędne jest, aby twórcy reprodukowanych w nich treści sięgali po nowe środki przekazu, podchodzili z dystansem do tego, co klasycznie rozumiemy przez pojęcia świata, przedmiotu, podmiotu i prawdy, oraz poświęcali prawdopodobność na rzecz kreatywności, otwierając nas tym samym na nowe i niepowtarzalne sposoby postrzegania i interpretowania.

\section{Odrzeczywistniona ontologia filmu animowanego}

Prowadzi mnie to do wspomnianego na samym początku filmu animowanego. W moim przekonaniu jest on formą sztuki, w której do opisywanego wyżej odrzeczywistnienia może dochodzić w stopniu najwyższym, a zatem ma on największy potencjał do wywoływania poczucia oscylacji. Animacja odznacza się mniej wyraźnym związkiem między światem przedstawionym a przedmiotami pochodzącymi ze świata rzeczywistego niż film aktorski. O ile w tym drugim poszczególne rekwizyty, aktorzy i elementy scenografii widziane są w sposób filmowy, a ich rzeczywiste pochodzenie brane jest w nawias i może być pomijane $\mathrm{w}$ procesie rozumienia filmu, o tyle ostatecznie są to jednak te same obiekty, na które moglibyśmy trafić, gdybyśmy wybrali się na spotkanie z twórcami czy odwiedzili studio filmowe. Akcja filmu aktorskiego może być odczytywana jako 
funkcja wydarzeń zachodzących w świecie widza - Roger Scruton zwraca wręcz uwagę, że „idealny” film czy zdjęcie są powiązane w sposób przyczynowo-skutkowy z istniejącymi obiektami i oddają te obiekty w podobny sposób, jak oddaje je lustro ${ }^{17}$. Po wyizolowaniu wpływu, jaki mogą wywierać praca kamery, zabiegi montażowe czy reprezentacyjne relacje fikcji (aktor nie występuje jako on sam, ale gra pewną fikcyjną postać), zasady rządzące światem filmu są podobne do zasad rządzących światem rzeczywistym - spektrum możliwych do wytworzenia obrazów jest więc w najbardziej dosłowny i przyziemny sposób ograniczone przez zasady rzeczywistości jako takie. Oczywiście zastosowanie rozmaitych filmowych tricków pozwala na przekonanie widza, że jest inaczej. Same te tricki również funkcjonują jednak w obrębie pozornie kwestionowanej przez siebie logiki zamiast za nią wykraczać - mogą one przekształcać nasze postrzeganie relacji przyczynowo-skutkowych, ale nie są w stanie im fundamentalnie zaprzeczyć $^{18}$. Nawet jeśli uważamy, że jeden $\mathrm{z}$ bohaterów zostaje postrzelony przez drugiego - więcej, widzimy to na ekranie - nie oznacza to, że został on rzeczywiście trafiony kulą. Twórcy filmu tradycyjnego mogą co najwyżej przekonać nas, że morderstwo miało miejsce, ale nie mogą pokazać morderstwa bez pozbawiania życia jednego $\mathrm{z}$ aktorów.

Film animowany odznacza się w tym względzie inną naturą. Jeżeli przyjrzymy się najbardziej podstawowej formie animacji, a więc wprawianiu w ruch rysunków, okaże się, że istnieje pewna nieredukowalna różnica pomiędzy materialną podstawą filmu animowanego a jego formą obserwowalną na ekranie. Tak jak film aktorski może być rozumiany jako pewna forma reprodukcji cech istniejących obiektów (nawet jeśli jest to celowo niedokładna i sugestywna reprodukcja, jak w przypadku omawianego wyżej postrzelenia jednego z bohaterów), tak film animowany z zasady ustanawia nowe właściwości rysunków. Choć można prześledzić i opisać złudzenie optyczne przekształcające nieruchome szkice w ruchome obiekty filmowe, w pewnym sensie są to radykalnie od siebie różne byty, podlegające odmiennym zasadom - eksplikacja wyłącznie relacji przyczynowo-skutkowych nie wystarcza do wykazania, w jaki sposób poszczególne rysunki stają się w oczach widza czymś więcej niż uporządkowanymi kształtami i plama-

17 Zob. R. Scruton, Photography and Representation, „Critical Inquiry” 1981, Vol. 7, No. 3, s. 577603.

18 Więcej na temat związku między zdjęciami i filmem a obiektami na nich widzianymi można przeczytać w K.L. Walton, Transparent Pictures: On the Nature of Photographic Realism, „Critical Inquiry" 1984, Vol. 11, No. 2, s. 246-277. 
mi barwnymi. Doskonałą tego ilustracją jest krótki metraż Czerwone i czarne $e^{19}$. Mam tu na myśli scenę, w której walczące ze sobą postaci odwracają lustro tak, że oczom widza ukazują się reżyser i operator kamery. W myśl proponowanej przeze mnie interpretacji, zaskoczenie tych ostatnich nie wynika jedynie $z$ tego, że stworzone przez nich postaci wystąpiły przeciwko nim. Dochodzi tu do szokującego przemieszania porządków - twórcy filmu mają ze swojej perspektywy do czynienia jedynie z serią następujących po sobie nieruchomych szkiców, przez co jakikolwiek wpływ świata animacji na rzeczywistość twórców powinien być niemożliwy w myśl zasad rządzących tym, co „prawdziwe”. Próba rozłożenia sekwencji na ciąg wydarzeń będących funkcją obiektów istniejących w świecie rzeczywistym nie przybliży nas do zrozumienia, co właściwie stało się na filmie.

Odwołując się ponownie do Scrutona, można powiedzieć, że w przeciwieństwie do fotografii i tradycyjnego filmu, rysunek i animacja nie opierają się przede wszystkim na związkach przyczynowo-skutkowych z istniejącymi obiektami (rysunki są jedynie materialną podstawą, a nie właściwą treścią animacji). Ich sposób bycia jest fundamentalnie związany $\mathrm{z}$ relacjami intencjonalności, które mogą nadać obserwowanym na filmie obiektom cechy odmienne od cech ich materialnej podstawy (i to w znacznie większym stopniu, niż dzieje się to w wypadku użycia tricków filmowych). Poszczególne obiekty rozpoznajemy jako to, co reprezentują, i to, co jest częścią naszego codziennego doświadczenia w wyniku określonej intencji twórców, która ma również wpływ na cechy, jakie jesteśmy skłonni w tych obiektach zaakceptować - w procesie interpretacji w różnym stopniu przyswajamy sobie myśli i perspektywę, którą autor animacji próbował przekazać. Intencjonalny ładunek zawarty w filmie animowanym nakazuje widzowi odczytywać poszczególne kształty właśnie jako postaci i scenografię, których ruchy składają się na konkretną historię, nawet jeśli materialna podstawa tych elementów w sposób oczywisty nie może być z nimi utożsamiana i nie mogłaby doprowadzić do takiego biegu wydarzeń. Daje to także twórcom ogromną swobodę dotyczącą formy reprezentacji poszczególnych elementów dzieła oraz ich granic, ponieważ właściwości bohaterów filmu animowanego związane są przede wszystkim z wyobraźnią twórców, a nie z fizycznymi właściwościami rzeczy istniejących w świecie rzeczywistym. I tak w Czerwonym i czarnym zarówno torreador, jak i byk mogą swobodnie zmieniać kształty, a nawet - swoją „naturę”, jak wtedy, gdy byk zamknięty w butelce od tuszu staje się właśnie tuszem.

19 W. Giersz, Czerwone i czarne, URL: https://www.youtube.com/watch?v=4t9Ffhb5PZY, dostęp: 6.06.2019. 
Powyższy przykład pozwala pokazać, jak kategorie odrzeczywistnienia i oscylacji mogą być wykorzystane do analizy filmu animowanego. To, co można w moim przekonaniu nazwać odrzeczywistniona ontologia filmu animowanego (odrzeczywistnioną, bo oddzieloną od świata rzeczywistego i rządzących nim zasad, a zbudowaną na intencjonalnych właściwościach dzieła - to przede wszystkim one, podobnie jak w malarstwie, oddają treść i charakter filmu animowanego), użyte zostało przez autorów Czerwonego i czarnego jako środek pozwalający wywołać szok, czy wręcz oscylację, nie tylko w widzach, ale także w samych twórcach występujących wewnątrz swojego dzieła. Reakcja operatora zakrywającego czapką obiektyw kamery może być rozumiana jako próba dopasowania pewnych przyzwyczajeń interpretacyjnych i pojęciowych do radykalnie odmiennej sytuacji, w której jako widz został on postawiony przez dzieło sztuki. Jeśli czymś podstawowym we wrażeniu oscylacji jest konfrontacja sztywnych, standardowych i uporządkowanych kategorii poznawczych z tym, co nie powinno mieć miejsca i nie może być zrozumiane, a mimo to zachodzi i musi podlec procesowi interpretacji, to specyfika środków, jakimi dysponuje animacja, może w znaczny sposób przyczyniać się do wytworzenia wrażenia oscylacji. Odrzeczywistnienie, cecha konstytutywna filmu animowanego oderwanego od swojej materialnej podstawy, zmusza widza do porzucenia utartych sposobów myślenia i do wytworzenia nowych, które mogłyby pomóc w dopasowaniu rozumienia do nowych zjawisk i nowych form przedstawiania istniejących już zjawisk.

Chociaż przywołany przeze mnie przykład dotyczy filmu rysunkowego, warto zaznaczyć, że jeszcze ciekawsza w analizie mogłaby okazać się animacja komputerowa, w której odrzeczywistnienie na poziomie związków między światem rzeczywistym a światem przedstawionym zachodzi w jeszcze większym stopniu. O ile materialna podstawa filmu rysunkowego odznacza się podobieństwem do obiektów świata filmu (można powiedzieć, że w podobnej relacji znajdują się obiekty świata rzeczywistego i ich zdjęcia - są tym samym dzięki relacjom reprezentacji, ale nie tym samym w sensie materialnej identyczności), to sytuacja komplikuje się jeszcze bardziej, gdy mowa o animacji komputerowej. Na gruncie materialnym, odpowiednikiem szkicu w tej formie twórczej byłby dysk twardy, na którym zapisany został zero-jedynkowy zapis animacji - odpowiednik treści rysunku. To, co z kolei rozumieć można jako najbliższy odpowiednik rysunku, z perspektywy wizualnej byłoby nieruchomą klatką na ekranie komputera, a więc już jakąś reprezentacją, odznaczającą się radykalnie innym statusem ontologicznym od swojej materialnej podstawy. Jak zauważa Rafe McGregor, popu- 
laryzacja technik komputerowych uwolniła film od ograniczeń związanych z tradycyjnymi metodami reprodukcji obrazu, „w związku z czym możliwy zakres reprezentacji powiększył się w sposób wykładniczy"20. Relacja między animacją komputerową a rzeczywistością, którą taka animacja mogłaby reprezentować, jest zatem mocno skomplikowana, ale bez wątpienia świat przedstawiony takiej animacji jest w chyba najmniejszym stopniu związany logiką rządzącą światem rzeczywistym ${ }^{21}$ (jakiekolwiek takie związanie wynikałoby raczej z intencji twórczych) i ma chyba największą możliwość mówienia za siebie.

\section{Reprezentacja w filmie animowanym}

Warto zastanowić się jeszcze nad samym pojęciem reprezentacji, które przywołałem kilkakrotnie w powyższych rozważaniach, jako że zasadnym kontrargumentem przeciwko mojej interpretacji mogłoby być stwierdzenie, że choć odrzeczywistnienie zachodzi $\mathrm{w}$ filmie animowanym na poziomie ontologicznym, to ograniczone jest ono w sposób istotny przez relacje reprezentacji, jakie zachodzą między światem filmu i światem rzeczywistym - wspomniane już Czerwone i czarne opiera się przecież na reprezentacji walki z bykiem, a więc związane jest wieloma zasadami pochodzącymi ze świata rzeczywistego. Przyznaję, że konieczność reprezentowania przedmiotów świata rzeczywistego może stanowić istotny limit dla kreatywności twórców, jednak chciałbym tu krótko przybliżyć dwa interesujące podejścia do kwestii reprezentacji możliwe na gruncie filmu animowanego. Pierwsze opiszę w związku z szeroko rozumianym filmem lal-

20 R. McGregor, A New/Old Ontology of Film, „Film-Philosophy” 2013. Vol. 17, No. 1, s. 273.

21 Interesujące w tym kontekście są rozważania Julie Lobalzo Wright (zob. J. Lobalzo Wright, Animation and the Star Body, „Film-Philosophy” 2019, Vol. 23, No. 2, s. 194-211), która zastanawia się nad związkiem między ciałem Mauiego z animacji Vaiana: Skarb Oceanu, a ciałem Dwayne’a Johnsona, które posłużyło za inspirację dla animatorów. Lobalzo Wright słusznie zauważa, że relacja między ciałami rzeczywistymi a ciałami wytworzonymi za pomocą animacji komputerowej jest bardzo skomplikowana, a relacje reprezentacji w podobnych wypadkach są przez widzów odczytywane dzięki rozmaitym odniesieniom kulturowym, powtarzaniu motywów i akcentowaniu podobieństw między wzorcem i reprezentacją. Szczególnie istotny dla mojego eseju jest nacisk na dodatkową plastyczność, jaką Lobalzo Wright przypisuje Mauiemu. Jego ciało może ulegać zmianom i wchodzić w konfiguracje niedostępne dla Johnsona, pokazując moim zdaniem ogromny potencjał tkwiący w animacji mogącej ukazywać to, co znane nam $\mathrm{z}$ rzeczywistości, w sposób całkowicie nowy, stymulując $\mathrm{w}$ ten sposób naszą wyobraźnię do tworzenia nowych obrazów świata. 
kowym, a drugie przedstawię na przykładzie filmu Begone Dull Care Normana McLarena ${ }^{22}$.

Animacja lalkowa jest formą animacji chyba najściślej związaną ze światem rzeczywistym - polega ona bowiem na wprawianiu w ruch istniejących $w$ tym świecie obiektów, a nie ich rysunków. Jednak przyjrzenie się filmom lalkowym, takim jak na przykład filmy Jana Švankmajera, pozwala dostrzec, że choć lalki i inne przedmioty stanowią materialną podstawę bohaterów filmu, to różnią się od nich na tyle, że nie sposób utrzymywać, aby bohaterowie reprezentowali tę podstawę w filmie. Ruchy, jakich dokonują postaci, przedmioty świata przedstawionego oraz transformacje, jakim ulegają, wskazują, że bohaterowie filmu nie oddają na ekranie jedynie cech swojej materialnej podstawy, ale nabierają nowych, wymykając się wielu ograniczeniom wyznaczonym przez świat rzeczywisty. O ile można powiedzieć, że stanowią oni reprezentację lalek, to warto zastanowić się, czy $w$ rzeczywistości nie bylibyśmy skłonni myśleć o tej relacji reprezentacji w sposób odwrotny - to bohater filmu jest właściwym przedmiotem podstawowym, a materialna podstawa jedynie jego lalką, oddającą w lepszy lub gorszy sposób wiele jego cech, ale nie samego bohatera.

Begone Dull Care pozwala z kolei zauważyć, że odwołanie do klasycznych relacji reprezentacji nie jest warunkiem koniecznym dla istnienia filmu animowanego. Choć krótki metraż McLarena składa się z wielu obiektów nałożonych lub namalowanych na taśmie filmowej, to nie można powiedzieć, że reprezentuje on te obiekty. W procesie animacji zostają one przekształcone w coś innego i reprezentują raczej treść i formę muzyki napisanej na potrzeby filmu. Zostają w związku z tym uwolnione od ograniczeń narzucanych przez relację reprezentacji, jaka powinna była zajść między obiektami „występującymi” w filmie a treścią filmu. Choć oczywiście McLaren nie wymaga od widzów zerwania ze wszelkimi dotychczasowymi formami postrzegania - odrzeczywistnienie nie zachodzi zatem w sposób całkowity, bo takie pełnie zerwanie jest niemożliwe ${ }^{23}$ - to umiejętnie ich dezorientuje, by przestroić ich nastawienia i oczekiwania percepcyjne, otwierając tym samym nową formę zestrojonego pojmowania muzyki i filmu.

22 N. McLaren, Begone Dull Care, URL: https://www.youtube.com/watch?v=0r2COvWPO4Y, dostęp: 6.06.2019.

23 Według Vattima zawsze zamieszkujemy w obrębie pewnej historycznodziejowej tradycji kulturowej i choć możemy ją przekształcać, to nie możemy występować z pozycji znajdującej się poza nią. Zob. G. Vattimo, Poza interpretacja, tłum. K. Kasia, Universitas, Kraków 2011, s. 91-111. 


\section{Zakończenie}

W świetle powyższych rozważań za zasadne uważam stwierdzenie, że filozofia Vattima może stanowić interesujące narzędzie do interpretacji filmu animowanego, a kluczowe dla jego analizy mediów kategorie oscylacji i odrzeczywistnienia wydają się szczególnie stosowne w odniesieniu do animacji. Starałem się wykazać, że odrzeczywistniona ontologia filmu animowanego oraz otwarta przez animację możliwość zerwania z klasycznymi relacjami reprezentacji prowadzić mogą do wytworzenia nowych sposobów pojmowania świata. Nietypowe obrazy i zaskakujące zabiegi stosowane przez twórców filmów animowanych mogą wywoływać $\mathrm{w}$ widzu poczucie dezorientacji będące warunkiem koniecznym do zaistnienia odpowiednich dla nich form interpretacji. Dzięki stosunkowo niewielkiemu związaniu zasad rządzących światem przedstawionym filmu animowanego i zasad rządzących światem rzeczywistym animacja jako forma sztuki dysponuje ogromnym potencjałem do wywoływania takiej dezorientacji, czy też oscylacji.

Sytuacja, w której autorzy filmów animowanych jak najczęściej staraliby się zrealizować ten potencjał, byłaby zatem czymś pożądanym (przynajmniej, jeśli podzielamy optymistyczną wizję rozwoju mediów masowych, jaki prezentuje Vattimo). Choć wpływ rynku na ograniczanie kreatywności twórców, jaki opisywał w swoich pracach autor Końca nowoczesności, również w wypadku filmów animowanych można uznać za istotny czynnik, to przedstawione przeze mnie cechy filmu animowanego wskazują, że sytuacja nie jest beznadziejna. Pozwala to żywić nadzieję, że rosnąca liczba eksperymentów dokonywanych także w animacjach głównego nurtu oraz siła ich oddziaływania na masowe imaginarium mogą doprowadzić do sytuacji, w której opisywany przeze mnie rodzaj filmowy w znaczący sposób przyczyniłby się do wywoływania wrażenia oscylacji i, co za tym idzie, rozszerzania spektrum tego, co uznajemy za zasadne sposoby rozumienia świata. Zbliżyłoby nas to tym samym do spełnienia etyczno-politycznych nadziei Vattima.

\section{Bibliografia}

Benjamin, W., Dzieło sztuki $w$ dobie reprodukcji technicznej, w: tegoż, Anioł historii. Eseje, szkice, fragmenty, tłum. J. Sikorski, Wydawnictwo Poznańskie, Poznań 1996, s. 201-240. 
D'Agostini, F., Vattimo's Theory of Truth, w: Between Nihilism and Politics: The Hermeneutics of Gianni Vattimo, eds. S. Benso, B. Schroeder, State University of New York Press, Albany, New York 2010, s. 33-46.

Giersz W., Czerwone i czarne, URL: https://www.youtube.com/watch? $\mathrm{v}=4 \mathrm{t} 9 \mathrm{Ffhb} 5 \mathrm{PZY}$, dostęp: 6.06.2019.

Heidegger, M., Źródło dzieła sztuki, w: tegoż, Drogi lasu, tłum. J. Mizera, Aletheia, Warszawa 1997, s. 7-62.

Marks, K., Proces wytwarzania kapitału, red. Paweł Hoffman, Bronisław Minc i Edward Lipiński Książka i Wiedza, Warszawa 1951, s. 76-89.

McGregor R., A New/Old Ontology of Film, „Film-Philosophy” 2013, Vol. 17, No. 1, s. 265-80.

McLaren N., Begone Dull Care, URL: https:/www.youtube.com/ watch?v=0r2COvWPO4Y, dostęp: 6.06.2019.

Scruton R., Photography and Representation, „Critical Inquiry” 1981, Vol. 7, No. 3, s. 577-603.

Sunstein, C. R., \#Republic: Divided Democracy in the Age of Social Media, Princeton University Press, Princeton 2017.

Vattimo, G., Poza interpretacją, tłum. K. Kasia, Universitas, Kraków 2011.

Vattimo, G., Społeczeństwo przejrzyste, tłum. M. Kamińska, Wydawnictwo Naukowe Dolnośląskiej Szkoły Wyższej Edukacji TWP, Wrocław 2006.

Vogt, E. M., Postmodernity as the Ontological Sense of Technology and Democratic Politics, w: Between Nihilism and Politics: The Hermeneutics of Gianni Vattimo, eds. S. Benso, B. Schroeder, State University of New York Press, Albany, New York 2010, s. 221-240.

Walton K. L., Transparent Pictures: On the Nature of Photographic Realism, „Critical Inquiry" 1984, Vol. 11, No. 2, s. 246-277.

Woodward A., Being and Information: On the Meaning of Vattimo, „Philosophy Today" 2016, No. 3(60), s. 723-41.

Wright Lobalzo J., Animation and the Star Body, „Film-Philosophy” 2019, Vol. 23, No. 2, s. 194-211.

Zabala S., Introduction: Gianni Vattimo and Weak Philosophy w: tegoż, Weakening Philosophy: Essays in Honour of Gianni Vattimo, McGill-Queen's University Press, Montreal, Kingston 2007, s. 1-34.

Zawadzki A., Koniec nowoczesności: nihilizm, hermeneutyka, sztuka, w: G. Vattimo: Koniec nowoczesności, tłum. M. Surma-Gawłowska, Universitas, Kraków 2006, s. V-XXI. 
Ziółkowska-Juś A., Doświadczenie estetyczne w świecie późnej nowoczesności. W horyzoncie hermeneutyki Gianniego Vattimo, „Estetyka i Krytyka” 2017, nr 2(45), s. 155-174.

\section{Streszczenie}

W artykule przedstawiam wybrane zagadnienia z obrębu filozofii mediów Gianniego Vattima, skupiając się przede wszystkim na pojęciu oscylacji, z którym włoski filozof wiąże nadzieje emancypacyjne. Opisując poszczególne cechy filmu animowanego z perspektywy filozofii mediów Vattima, argumentuję, że animacja jest dziedziną sztuki w najwyższym stopniu pasującą do teorii autora Końca nowoczesności. Rozwój eksperymentalnych form animacji powinien w związku z tym przyczynić się w ogromnym stopniu do spełnienia etyczno-politycznych nadziei Vattima.

Słowa kluczowe: Gianni Vattimo, film animowany, oscylacja, odrzeczywistnienie, emancypacja, hermeneutyka, estetyka

\section{Summary}

\section{Animated Film from the Perspective of Gianni Vattimo's Philosophy of Media}

In this paper, I overview selected ideas central to Gianni Vattimo's philosophy of media, while focusing on the idea of oscillation, to which the Italian philosopher attached some emancipatory hopes. By describing certain aspects of animated film from the perspective of Vattimo's philosophy of media, I argue that animation is the form of art most fitting to the theory proposed by the author of The End of Modernity. As a result, the development of experimental forms of animation should contribute to a great extent to the fulfilment of Vattimo's ethicopolitical hopes.

Key words: Gianni Vattimo, animated film, oscillation, derealisation, emancipation, hermeneutics, aesthetics 